\title{
Use of community resources before inflammatory bowel disease surgery is associated with postsurgical quality of life
}

\author{
David Norman Moskovitz $\mathrm{BSc}^{1}$, Robert Gordon Maunder MD FRCPC ${ }^{2}$, Zane Cohen MD FRCSC $^{3}$, \\ Robin Susan McLeod MD FRCSC ${ }^{3}$, Helen MacRae MD FRCSC ${ }^{3}$
}

DN Moskovitz, RG Maunder, Z Cohen, RS McLeod, H MacRae. Use of community resources before inflammatory bowel disease surgery is associated with postsurgical quality of life. Can J Gastroenterol 2000;14(2):95-98.

BACKGROUND: Research in chronic illness shows that community resources can have a lasting influence on the course of the illness; however, little research has been done to evaluate the community agencies that specifically address the needs of inflammatory bowel disease (IBD) patients.

OBJECTIVES: To survey awareness of community agency resources among patients who have surgery for IBD, and to analyze the association between using these resources and qualitative postsurgical outcomes.

SUBJECTS AND METHODS: Ninety-two subjects who had surgery over a 12-month period completed, in full, the Inflammatory Bowel Disease Questionnaire (IBDQ), and a self-report instrument used to probe awareness and use of local community resources. Community resources were divided into two groups: those involving primarily social and educational participation ('social/ educational') and those involving some individualized attention, usually from a professional or trained lay facilitator ('professional/individual'). The contribution of presurgical participation in each type of resource to postsurgical quality of life was tested using ANOVA, with IBDQ score as the dependent variable. The ANOVA was repeated with postsurgical disease activity as a covariable. IBDQ subscale scores were compared between groups that were found to differ in the ANOVA.

RESULTS: Almost all subjects were aware of at least one available resource. Participation in resources before surgery was variable, but $50 \%$ of the sample participated in at least one social/educational resource, and $46.9 \%$ participated in at least one professional/individual support. For the 92 subjects who completed both the IBDQ and the survey of resources, ANOVA revealed a main effect of professional/individual resource use on postsurgical quality of life but no main effect of social/educational resources and no interaction.

DISCUSSION: The association between presurgical participation in professional or individualized community resources and better subjective outcome of IBD surgery may be explained by a positive contribution of participation to coping with surgery for IBD. The data do not support the alternative explanation that subjects with less severe disease (and thus better outcome) have greater ability to participate, although further research is required.

Key Words: Community resources; Inflammatory bowel disease; Surgery

L'utilisation de ressources communautaires avant une chirurgie pour une maladie inflammatoire de l'intestin est associée à la qualité de vie postchirurgicale

HISTORIQUE : Les recherches sur les maladies chroniques montrent que les ressources communautaires peuvent avoir une influence prolongée sur l'évolution de la maladie; cependant, les recherches visant à évaluer les organismes communautaires qui s'occupent spécifiquement des besoins

voir page suivante

${ }^{1}$ Faculty of Medicine, University of Toronto; ${ }^{2}$ Department of Psychiatry, University of Toronto, and Department of Psychiatry, Mount Sinai Hospital; ${ }^{3}$ Department of Surgery, University of Toronto, Toronto, Ontario

Correspondence and reprints: David Moskovitz, Department of Surgery, 4th Floor, Suite 451, Mount Sinai Hospital, Toronto, Ontario

M5G 1X5. Telephone 416-586-8396, fax 416-586-8644, e-mail david.moskovitz@utoronto.ca

Received for publication November 26, 1998. Accepted July 14, 1999 
des patients atteints d'une maladie inflammatoire de l'intestin (MII) sont peu nombreuses.

OBJECTIFS : Interroger les patients qui subissent une chirurgie pour une MII quant à leur connaissance de ressources offertes par des organismes communautaires et analyser l'association entre l'utilisation de ces ressources et le degré de qualité de vie postchirurgicale.

SUJETS ET MÉTHODES : Quatre-vingt-douze sujets qui ont subi une chirurgie au cours des 12 derniers mois, ont rempli, dans sa totalité, le Questionnaire sur les maladies inflammatoires de l'intestin (QMII), et complété un formulaire d'enquête visant à évaluer leur connaissance et leur utilisation de ressources communautaires locales. Les ressources communautaires ont été divisées en deux groupes : le groupe des ressources faisant principalement appel à une participation sociale et éducationnelle (sociale-éducationnelle) et le groupe des ressources faisant appel à une certaine forme d'aide individualisée, habituellement offerte par un professionnel ou un travailleur communautaire expérimenté (professionnel-individuel). La contribution de la participation préchirurgicale dans chaque groupe de ressources à la qualité de vie a été testée par analyse de la variance (ANOVA), en utilisant la cotation du QMII comme variable dépendante. L'analyse de la variance a été répétée en utilisant l'activité de la maladie après la chirurgie comme covariable. Les scores des sous-échelles du QMII ont été comparés entre les groupes qui se révélaient différents dans l'ANOVA.

RÉSULTATS : Presque tous les sujets savaient qu'il existait au moins une ressource. La participation aux ressources avant la chirurgie était variable, mais $50 \%$ de l'échantillon avait participé au moins à une ressource sociale-éducationnelle, et 46, 9 \% avait participé au moins à un soutien professionnel-individuel. Pour les 92 sujets qui avaient rempli à la fois le QMII et le formulaire d'enquête sur les ressources, l'ANOVA a mis en évidence un effet majeur de l'utilisation de la ressource professionnelle-individuelle sur la qualité de vie postchirurgicale mais aucun effet appréciable de l'utilisation des ressources sociales-éducationnelles et aucune interaction.

DISCUSSION : L'association entre la participation aux ressources communautaires individualisées ou professionnelles avant la chirurgie et des résultats subjectivement meilleurs de la chirurgie pour une MII peut s'expliquer par une contribution positive de la participation pour faire face à ce type de chirurgie. Les données n'étayent pas l'autre explication selon laquelle les sujets atteints d'une maladie moins sévère (donc avec une évolution meilleure) peuvent mieux participer ; néanmoins, d'autres recherches s'imposent.
$\mathrm{P}$ eer support has the potential to offer benefits to people with chronic illnesses that are not as readily available through traditional medical settings, such as the perception of shared understanding and the benefits associated with altruism and modelling. In addition, the high degree of lay participation in peer support groups compared with medical settings results in lower costs. As a result, community agencies have become increasingly important to both health care professionals and patients in the management of chronic illness. Furthermore, as the delivery of health care shifts toward community-based care, the role of community agencies is likely to expand.

Seeking and receiving help, and providing help to others are major forms of coping activity (1). The availability of someone to provide emotional or practical support may protect individuals from some of the negative consequences of major illness (2,3). Participation in community agencies is one form of social support that is readily available in many settings. While research in other conditions shows that community resources can have a lasting influence on the course of the illness (4), little research has been done to evaluate community agencies specifically designed to address the needs of people with inflammatory bowel disease (IBD). In community support groups, participation has been reported to be as low as $20 \%$ of eligible participants (5).

It has been estimated that $70 \%$ to $80 \%$ of people with Crohn's disease (6) and 30\% of people with ulcerative colitis (7) will have at least one operation in their lifetime. The need for surgery has been found to be among the most significant concerns contributing to health-related quality of life in IBD patients (8). Surgical outcomes, therefore, are an important area in which to assess the impact of community resources. The present study surveyed the awareness of community agency resources among patients who have had surgery for IBD, and analyzed the association between using these resources and qualitative postsurgical outcomes.

\section{SUBJECTS AND METHODS}

Of 219 patients who underwent surgery for Crohn's disease or ulcerative colitis at Mount Sinai Hospital, Toronto, Ontario between September 5, 1996 and September, 29 1997, 145 could be contacted by telephone and were invited to participate in the study. Fifteen patients declined. One hundred and thirty questionnaires were distributed by mail for self-administration. Participants who did not return the questionnaire after one month received one telephone call. Ninety-eight questionnaires (68\% of those contacted) were returned; six were partially complete. The instruments included a demographic questionnaire, a measure of healthrelated quality of life (Inflammatory Bowel Disease Questionnaire [IBDQ]), and an instrument probing awareness of and participation in local community resource activities related to IBD.

The IBDQ is a 32 -item self-administered questionnaire used to measure the health-related quality of life of IBD patients that is sensitive to between-group differences (9). The IBDQ yields a total score, from 32 to 224, of IBD-related quality of life and subscales for quality of life related to bowel symptoms, systemic symptoms, emotional issues and social activity. Higher scores indicate better quality of life.

A self-report instrument was developed to probe awareness of local community resources. A list of the community services available to IBD patients was generated through conversation with IBD patients, gastroenterologists, nurses and staff at specific community agencies, and from the Blue Book, a comprehensive database of community services in Toronto (The Community Information Centre of Metropolitan Toronto, Toronto, Ontario). The agencies listed in the questionnaire were the Crohn's and Colitis Foundation of Canada, the United Ostomy Association of Canada, the Victoria Order of Nurses, St Elizabeth Visiting Nursing Association and the IBD centre at Mount Sinai Hospital. An extensive list of services was created, and screened for appli- 
cability and comprehensiveness by experienced members of the staff of the IBD centre. For each service, subjects were asked whether they were aware of this service before surgery and how many times they had participated in it before surgery.

Symptom severity was estimated as the sum of three selfreported symptoms - abdominal pain, frequency of diarrhea and general well being - each reported on a four-point Likert scale, a method that has previously been found to correlate highly with the Crohn's Disease Activity Index (5).

For analysis of the data, community resources were organized into two groups according to their format and the training of leaders. Resources that involve individual attention from trained persons (generally nurses but including physicians, other health professionals and trained lay visitors) were distinguished from resources involving primarily educational lectures, support meetings by untrained facilitators or social contact. The contribution of presurgical participation in each type of resource to postsurgical quality of life was tested using a one-way ANOVA, with IBDQ score as the dependent variable and membership in each resource group as two independent variables. The ANOVA was then repeated with postsurgical disease activity as a covariable. IBDQ subscale scores were compared between groups that were found to differ in the ANOVA. Values of P were calculated for two-tailed tests of significance using the Bonferroni correction for multiple comparisons.

Statistical analyses were performed with SPSS software (SPSS Inc, Chicago, Illinois).

\section{RESULTS}

Of 92 subjects who completed both the resource questionnaire and the IBDQ, 43 (47\%) were men and 49 (53\%) were women. The mean age was 38.0 years (range 17 to 71 years). The mean age at onset of symptoms was 27.6 years (range six to 68 years). Forty-six (50\%) had ulcerative colitis, while 43 (47\%) had Crohn's disease and three $(3 \%)$ did not know their diagnosis. Thirty-one subjects (34\%) had pelvic pouch surgery (ileal pouch-anal anastomosis), and 61 (66\%) had a bowel resection or other type of surgery. Subjects were contacted several months after surgery (mean 9.0 months, range three to 15 months). Mean IBDQ score did not differ significantly between groups defined by sex (mean \pm SD: males $159.90 \pm 40.87$; females $164.29 \pm 32.35$ ), diagnosis (ulcerative colitis 157.38 \pm 40.34 ; Crohn's disease $166.53 \pm 32.70$ ) or type of surgery (pelvic pouch 155.05 \pm 39.36 ; other surgery $165.89 \pm 34.63)$. Time since surgery was not correlated with IBDQ score or that of its subscales.

Awareness of community resources in general was high. Almost all of the 98 subjects who completed the survey of resource use were aware of at least one available resource ( $\mathrm{Ta}$ ble 1). Awareness of individual resources ranged from $20 \%$ to $75 \%$. Participation in resources was also variable. Of the 92 subjects who completed the survey of resource use and the IBDQ, twenty-two (24\%) participated in at least one social/educational resource but no professional/individual resources. Twenty subjects (22\%) participated in a profes-
TABLE 1

Percentage of 98 postsurgical inflammatory bowel disease patients who endorse awareness of and participation in specific community resources before surgery

\begin{tabular}{|c|c|c|c|}
\hline & Agency & Awareness & Participation* \\
\hline \multicolumn{4}{|l|}{ Educational/social resources } \\
\hline Speaker series & CCFC & 41.8 & 16.3 \\
\hline Charity day & CCFC & 50.0 & 16.3 \\
\hline Newsletters and/or books & CCFC & 64.3 & 12.2 \\
\hline Pelvic pouch support group & $\mathrm{MSH}$ & 45.9 & 11.2 \\
\hline Chapter meetings & CCFC & 40.8 & 9.2 \\
\hline Heel n' Wheel a Thon & CCFC & 27.6 & 6.1 \\
\hline Local community centres & & 40.8 & 6.1 \\
\hline Support group meetings & UOA & 22.4 & 5.1 \\
\hline Ostomy quarterly magazine & UOA & 22.4 & 5.1 \\
\hline $\begin{array}{l}\text { Any educational/social } \\
\text { resources }\end{array}$ & & 91.8 & 50.0 \\
\hline \multicolumn{4}{|l|}{ Professional/individual resources } \\
\hline Visiting nurse & St $\mathrm{E}$ & 35.7 & 18.4 \\
\hline Enterostomal therapist & $\mathrm{MSH}$ & 37.8 & 15.3 \\
\hline Visiting nurse & VON & 75.5 & 13.3 \\
\hline Patient visiting service & UOA & 20.4 & 8.2 \\
\hline Group psychotherapy & $\mathrm{MSH}$ & 46.9 & 5.1 \\
\hline Art or music therapy & & 20.4 & 0.0 \\
\hline $\begin{array}{l}\text { Any professional/ individual } \\
\text { resource }\end{array}$ & & 91.8 & 46.9 \\
\hline \multicolumn{4}{|l|}{ Other resources } \\
\hline Homemaker & & 44.9 & 6.1 \\
\hline Child care services & & 31.6 & 1.0 \\
\hline Any resource & & 98.0 & 78.6 \\
\hline
\end{tabular}

sional or individualized resource only. Twenty-six subjects (28\%) did not participate in any of the resources surveyed, and twenty-four subjects (26\%) participated in both professional/individual and social/educational resources.

For the 92 subjects who completed both the IBDQ and the survey of resources, ANOVA revealed a main effect of professional/individual resource use on postsurgical quality of life but no main effect of social/educational resources and no interaction (Table 2).

Repeating the ANOVA with disease activity as a covariable results in a nonsignificant contribution of professional resource use $(\mathrm{F}=2.52, \mathrm{P}=0.116)$. This is expected because the IBDQ is highly correlated with disease activity (correlation coefficient $-0.50, \mathrm{P}<0.001$ ).

Table 3 illustrates the relationship between preoperative use of professional/individual resources and the facets of postoperative quality of life measured by the IBDQ subscales: bowel, systemic, emotional and social problems. Patients who received professionally trained social support differed significantly in postoperative quality of life from those who received no resources in total IBDQ, systemic symptoms and emotional problems. 
TABLE 2

ANOVA of the contribution of professional/individual resource use, social/educational resource use and a combination of the two to health-related quality of life (Inflammatory Bowel Disease Questionnaire)

\begin{tabular}{|c|c|c|c|c|c|}
\hline $\begin{array}{l}\text { Source of } \\
\text { variation }\end{array}$ & $\begin{array}{l}\text { Sum of } \\
\text { squares }\end{array}$ & $\begin{array}{l}\text { Degrees of } \\
\text { freedom }\end{array}$ & $\begin{array}{l}\text { Mean } \\
\text { square }\end{array}$ & $\mathbf{F}$ & $\mathbf{P}$ \\
\hline Main effects & 8621.85 & 2 & 4310.92 & 3.38 & 0.038 \\
\hline $\begin{array}{l}\text { Professional/ } \\
\text { individual }\end{array}$ & 7842.19 & 1 & 7842.19 & 6.15 & 0.015 \\
\hline $\begin{array}{l}\text { Social/ } \\
\text { educational }\end{array}$ & 403.44 & 1 & 403.33 & 0.32 & 0.58 \\
\hline Combination* & 51.53 & 1 & 51.53 & 0.04 & 0.84 \\
\hline Total & 120837.65 & 91 & 1327.89 & & \\
\hline
\end{tabular}

*Professional/individual and social/educational

\section{DISCUSSION}

This study suggests that using community supports contributes to a better subjective outcome of surgery for IBD. Use of supportive resources was correlated with a higher quality of life in our sample, which is consistent with the reported value of social support for medical outcomes in general (2). Furthermore, the survey data suggest that in a metropolitan area with a broad range of disease-specific resources available, patients with IBD report good overall resource awareness and a high rate of participation, approximately $75 \%$. This is substantially higher than the previously reported rate of $20 \%$ (5), which may indicate relatively greater accessibility of community agencies or higher motivation among IBD patients in our sample. The results of our study suggest a high motivation among subjects. It is important to note that the study, which targeted every patient receiving surgery for IBD during the study period, received a response rate of $68 \%$. This suggests that this sample is likely to be typical of patients at our centre.

Different types of community resources were associated with different outcomes in our sample. Participation in professionally trained and facilitated resources was associated with a better postoperative quality of life than was nonparticipation, whereas this difference was not significant for participants in educational and social resources. Participation in professional resources is distinguished from no participation in professional resources by improved postoperative IBD emotional and systemic symptoms. These results suggest that trained personnel providing individualized services to IBD patients contribute positively to postsurgical quality of life; the contribution of less intensive services was not detected with our outcome measure and sample size.

The retrospective design of this study requires a caveat to this conclusion. Participation in community agencies may require a degree of illness stability such that people with more severe symptoms may not be physically able to participate. The results suggest that (postsurgical) disease activity was highest in subjects who were (presurgical) nonparticipators, which may support disease activity as the primary determinant of both resource participation and quality of life
TABLE 3

Relationship between preoperative use of professional/ individual resources and the Inflammatory Bowel Disease Questionnaire (IBDQ) subscales

\begin{tabular}{lccl}
\hline IBDQ subscale & Participated & $\begin{array}{c}\text { Did not } \\
\text { participate }\end{array}$ & \multicolumn{1}{c}{ P } \\
\hline Bowel problems & 50.97 & 46.49 & 0.046 \\
Systemic problems & 40.04 & 35.51 & $0.007^{*}$ \\
Social problems & 25.08 & 25.95 & 0.024 \\
Emotional problems & 55.14 & 48.14 & $0.012^{*}$ \\
\hline
\end{tabular}

*Statistically significant $(P<0.02)$ by t test using Bonferroni correction

outcome. We argue against this interpretation because the most frequently used resources in the 'professional' group (home visits by community nurses and lay visitors) appear to require less active effort for participation than the resources in the social/educational group (ie, in general people need to feel better to go out to an educational night or a fundraising event than to be visited by a nurse). If disease activity were the primary determinant of participation, we would expect to find the lowest level of disease activity in the users of social educational groups, which the data do not support. Clearly, further prospective research is required to investigate the interaction of presurgical disease activity, presurgical resource use and postsurgical quality of life. Failure to consider postoperative complications as a determinant of postoperative quality of life was another limitation of our study.

This study supports the role of community service groups in the health care system, particularly resources provided by trained personnel. As a result, greater ties between service groups and health care professionals are suggested. Working together to design programs and train program leaders may improve the overall health of patients with IBD.

\section{REFERENCES}

1. Wilcox BL, Vernberg EM. Conceptual and theoretical dilemmas facing social support. In: Sarason IG, Sarason BR, eds. Social Support: Theory, Research and Applications. The Netherlands: Martinus Nijhoff, 1985.

2. Sherbourne CD. The role of social supports and life stress events in the use of mental health services. Med Care 1988;27:1393-400.

3. Moskovitz DN, Maunder RG, Cohen Z, McLeod RS, MacRae, H. Coping Behaviour and Social Support Contribute Independently to Higher Quality of Life after Surgery for Inflammatory Bowel Disease. Dis Colon Rectum. (In press)

4. von Wietersheim J, Köhler T, Feiereis H. Relapse-precipitating life events and feelings in patients with inflammatory bowel disease. Psychother Psychosom 1992;58:103-12.

5. Rees JEP, Mayberry JF, Calcraft B. What the patient wants to know about Crohn's disease. J Clin Gastroenterol 1983;5:221-2.

6. Shorb PE. Surgical therapy for Crohn's disease. Gastroenterol Clin North Am 1989;18:111-28.

7. Cohen Z. Why not just cut out my disease? Can J Gastroenterol 1994;8:53-9.

8. Drossman DA. Psychosocial factors in ulcerative colitis and Crohn's disease. In: Kirsner JB, Shorter RG, eds. Inflammatory Bowel Disease, 4th edn. Baltimore: Williams and Wilkins, 1995:492-513.

9. Guyatt G, Mitchell A, Irvine E, et al. A new measure of health status for clinical trials in inflammatory bowel disease. Gastroenterology 1989;96:804-10. 


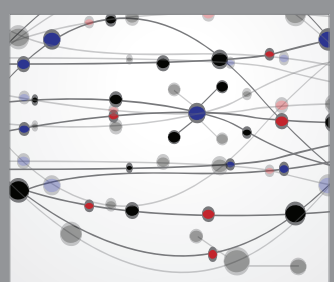

The Scientific World Journal
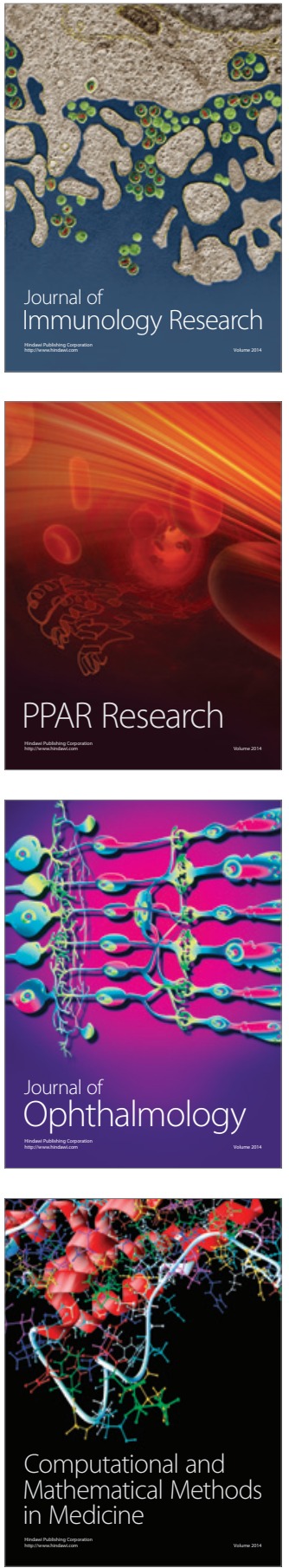

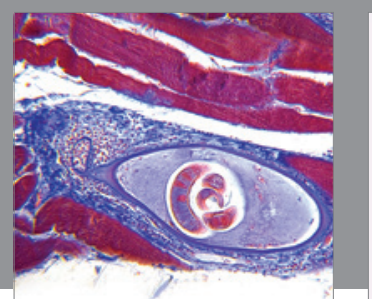

Gastroenterology Research and Practice

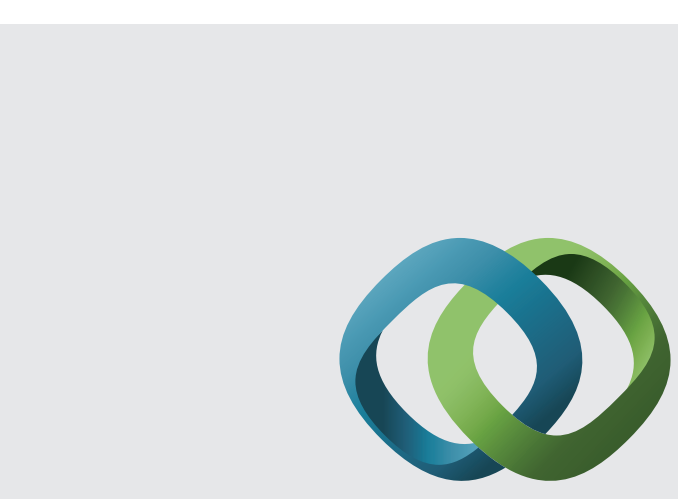

\section{Hindawi}

Submit your manuscripts at

http://www.hindawi.com
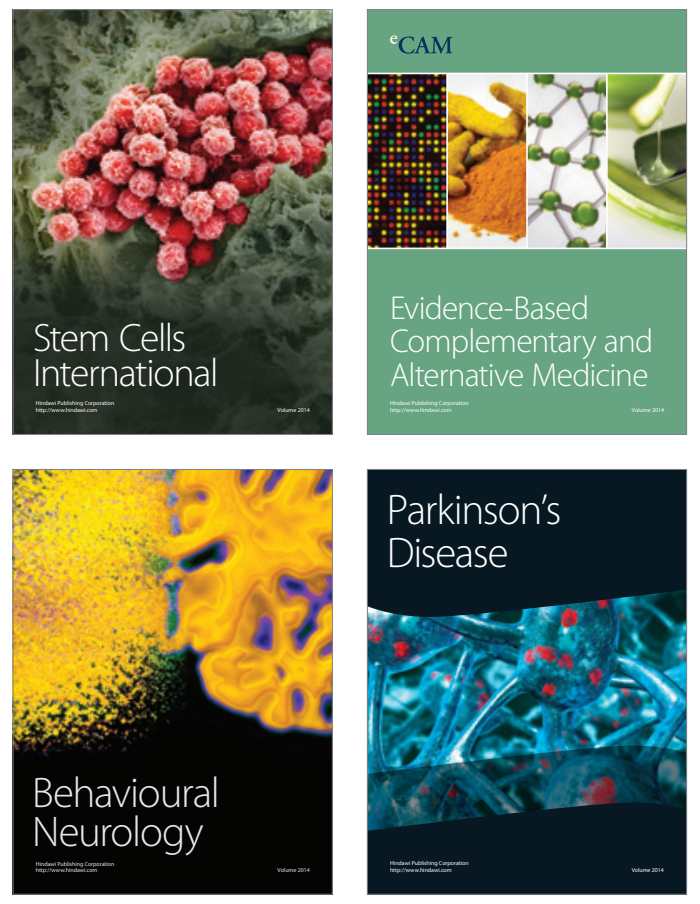
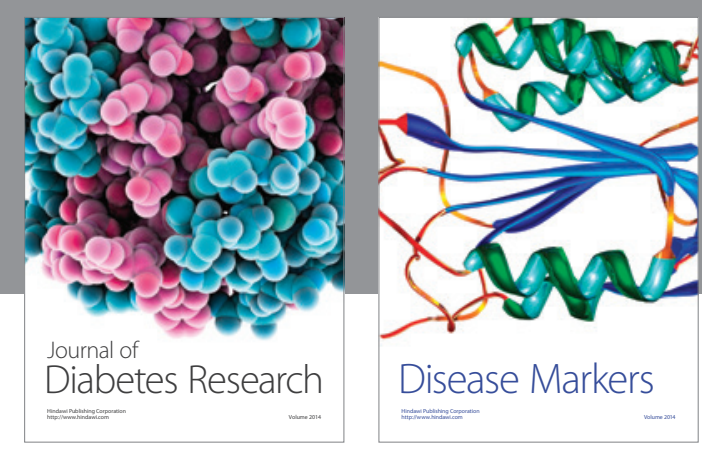

Disease Markers
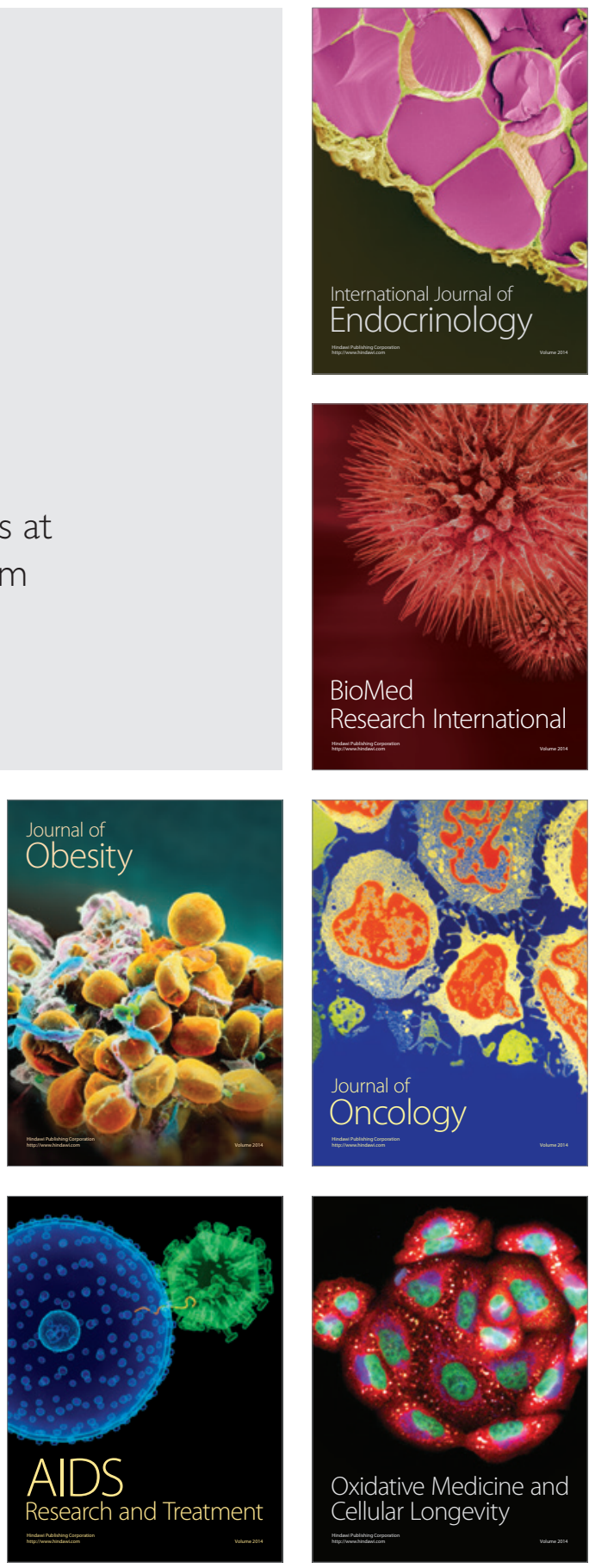